\author{
Kamila Kacprzak \\ Uniwersytet Kazimierza Wielkiego w Bydgoszczy
}

\title{
Interpretacyjna analiza fenomenologiczna. Charakterystyka podejścia i możliwości zastosowania w pedagogice/andragogice*
}

\author{
Interpretative Phenomenological Analysis. \\ Characteristics of the approach and the possibility of its \\ application in pedagogy/andragogy
}

Streszczenie. Celem niniejszego artykułu jest próba krytycznej analizy i oceny publikacji naukowej dotyczącej Interpretacyjnej analizy fenomenologicznej (ang. Interpretative phenomenological analysis - IPA), której autorami są: Jonathan A. Smith, Paul Flowers i Michael Larkin (2009), w kontekście możliwości wykorzystania tego podejścia w pedagogice, w tym także $\mathrm{w}$ andragogice. IPA coraz częściej wykorzystywana jest przez przedstawicieli nauk humanistycznych, społecznych czy nauk o zdrowiu, dotychczas jednak nie podjęto próby wprowadzenia tego podejścia do pedagogiki andragogiki, w której swoją tradycję ma już perspektywa hermeneutyczno-fenomenologiczna.

Słowa kluczowe: Interpretacyjna analiza fenomenologiczna; podejścia badawcze; badania jakościowe; pedagogika, andragogika.

Summary. The aim of this article is to critically analyze and evaluate scientific publication concerning the Interpretative Phenomenological Analysis (IPA), written by Jonathan A. Smith, Paul Flowers and Michael Larkin (2009), in the context of the potential of using the approach in pedagogy and also in andragogy. IPA is used more often by representatives of the humanities, social sciences, and health sciences, but so far no attempt was made to introduce this approach to pedagogy-andragogy in which hermeneuticphenomenological perspective has already been used.

Keywords: Interpretative Phenomenological Analysis, research approaches, qualitative research, pedagogy, andragogy.

\footnotetext{
* Autorka jest stypendystką programu dla doktorantów Narodowego Centrum Nauki.
} 


\section{Interpretacyjna analiza fenomenologiczna jako podejście badawcze}

Według Jonathana A. Smitha, Paula Flowersa i Michaela Larkina, autorów podręcznika Interpretative Phenomenological Analysis. Theory, Method and Research, interpretacyjna analiza fenomenologiczna (w skrócie IPA) ma krótką i jednocześnie długą historię. Pierwszy realny ślad pochodzi z publikacji Jonathana Smitha (1996). Autor argumentował, że psychologii potrzebne jest podejście będące jednocześnie empirycznym i jakościowym; zdolnym wejść $\mathrm{w}$ dialog $\mathrm{z}$ dominującym nurtem $\mathrm{w}$ psychologii. $\mathrm{W}$ artykule podnoszono kwestię przywrócenia tej dyscyplinie naukowej bardziej pluralistycznego charakteru, tak jak to sobie wyobrażał William James. IPA stała się podejściem, które podlega silnym wpływom ważnych teoretycznych idei. Autorzy podręcznika odnoszą się do rozważań najważniejszych filozofów: Edmunda Husserla, Martina Heideggera, Maurice'a Merleau-Ponty'ego, Jean-Paula Sartre'a, Friedricha Schleiermachera, Hansa-Georga Gadamera. Twórcy podręcznika podjęli próbę zoperacjonalizowania najistotniejszych założeń perspektywy hermeneutycznej i fenomenologicznej oraz dokonania syntezy w ich obrębie. Celem tego zabiegu miało być opracowanie podejścia, w którym wykorzystano by idee fenomenologii i hermeneutyki w pracy badawczej (Smith, Flowers, Larkin 2009, s. 4)

Pierwotnie IPA wykorzystywana była do konstruowania projektów badawczych z zakresu psychologii zdrowia. Nie jest to jednak podejście ograniczone tylko dla tej subdyscypliny naukowej czy związane z koniecznością posiadania przez badaczy formalnego wykształcenia w tym zakresie. Coraz częściej IPA jest wykorzystywana przez przedstawicieli nauk humanistycznych, społecznych czy nauk o zdrowiu. Większość wcześniejszych prac powstała w Wielkiej Brytanii, później podejście zostało rozpowszechnione w innych anglojęzycznych krajach. W ostatnim czasie zauważono, że zainteresowanie IPA pojawiło się także w krajach, gdzie język angielski nie jest językiem wiodącym (Smith, Flowers, Larkin 2009, s. 5). W Polsce tłumaczenie wspomnianego podręcznika nie jest dostępne, ale przybliżeniem polskiemu badaczowi kwestii praktycznego wykorzystania interpretacyjnej analizy fenomenologicznej w badaniach jakościowych w psychologii zajął się Igor Pietkiewicz (2012). Powstało także kilka artykułów, w których prezentowane są prowadzone badania i ich rezultaty interpretowane przy pomocy IPA (zob. Pańczak, Pietkiewicz 2015; I. Pietkiewicz 2015). Celem niniejszego artykułu jest próba krytycznej analizy i oceny publikacji naukowej dotyczącej IPA w kontekście możliwości wykorzystania tego podejścia w pedagogi- 
ce, w tym także w andragogice. Ze względu na ograniczone ramy niniejszego opracowania pominięta zostanie kwestia metodyki pracy badawczej, warto zapoznać się ze wspomnianym tekstem I. Pietkiewicza (2012).

Przedmiotem zainteresowania badaczy IPA jest położenie człowieka jego dylematy i kłopoty lub szerzej - jego radzenie sobie w świecie i ze światem. IPA jest podejściem w badaniach jakościowych, w ramach którego bada się, w jaki sposób ludzie nadają sens swoim istotnym życiowym doświadczeniom. Niezależnie od tego, czego dotyczą te doświadczenia, czego są rezultatem, ani jak zostały ocenione, mają one osobiste znaczenie dla człowieka, aktywnie angażującego swoje myśli i uczucia w interpretację zjawisk, obiektów i ludzi, których spotyka w swoim życiu. Dostęp do doświadczeń respondentów zawsze zależy od tego, co sami badani o nich powiedzą. Badacz może zrozumieć to doświadczenie dopiero po tym, jak zinterpretuje otrzymane wyjaśnienie, opis, relację (Smith, Flowers, Larkin 2009, s. 1-5).

IPA odwołuje się do podstawowych zasad fenomenologii, hermeneutyki i idiografii. Należy zauważyć, że prekursorzy tego podejścia nie operacjonalizują i nie utożsamiają IPA z jednym twórcą czy jedną „słuszną" koncepcją filozoficzną. Dokonują syntezy nie tylko w obrębie fenomenologii i hermeneutyki, ale także łączą te dwa podejścia. Rezultatem zastosowania takiego rozwiązania jest metoda będąca w swej naturze zarówno deskryptywna (opisuje, jak rzeczy się jawią), jak i interpretacyjna (rzeczy mają swoje niewidoczne znaczenie). Już Martin Heidegger mówił o tym, że rzeczy się nam jawią, ale ich ukryty sens może być ujawniony w trakcie procesu analitycznego (Smith, Flowers, Larkin, 2009, s. 23-25, 34-35).

Punktem wyjścia w budowaniu podstaw teoretycznych IPA uczyniono życiowe doświadczenie człowieka. Samo doświadczenie jest nieuchwytne i niedostępne, stajemy się jego świadomi dopiero po wydarzeniu. Mówiąc o badaniach, których celem jest dotarcie do doświadczeń, mamy na myśli badania, które są „bliskie doświadczeniom”. Człowiek jest istotą „samointerpretującą się" i jako uczestnik doświadczenia, nie nadaje znaczenia samemu doświadczeniu. Znaczenie otrzymuje wyłącznie reprezentacja tego doświadczenia. Innymi słowy, gdy aktywność człowieka (pamiętanie, żałowanie, pożądanie itd.) staje się doświadczeniem, to interesuje ona badacza IPA z tego powodu, że jest subiektywnym doświadczaniem czegoś. Czegoś, co dla jednostki staje się znaczące i unikalne (Smith, Flowers, Larkin 2009, s. 32-33). W tym sensie IPA czerpie $z$ fenomenologii. Jednakże w ramach tego podejścia podkreśla się, że prowadzenie czynności badawczych to dynamiczny proces, w którym aktywną rolę odgrywa także badacz - takie założenie jest bliższe podejściu hermeneutycznemu. Badacz próbuje przybliżyć się 
do świata przeżyć respondenta, ale nie może do niego dotrzeć bezpośrednio lub całkowicie, ponieważ dostęp do niego zależy od założeń badacza i jest przez nie zakłócany. Stąd do zrozumienia doświadczenia innych osób konieczne jest uruchomienie procesu interpretacji określanego w kategoriach podwójnej hermeneutyki - w pierwszej kolejności badany nadaje sens zjawiskom w swoim świecie, a następnie badacz próbuje odkodować owe znaczenia - nadać sens interpretacjom tworzonym przez badanych. Dlatego IPA jest poznawczo połączona $\mathrm{z}$ hermeneutyką i teoriami interpretacji (Smith, Osborn 2014, s. 53).

W odniesieniu do relacji pomiędzy naszymi przedzałożeniami (ang. fore-conception) i pracą interpretacyjną związaną ze zrozumieniem fenomenu, autorzy podręcznika odwołują się do myśli Heideggera oraz Gadamera. Twierdzili oni, że dopiero na skutek kontaktu z fenomenem, który się nam jawi, uświadamiamy sobie własne przedstruktury i proces ten stale odnawia się w kole hermeneutycznym - koncepcje są porównywane, kontrastowane ze sobą i modyfikowane, jako część procesu nadawania znaczeń (Smith, Flowers, Larkin 2009, s. 26, 34-36).

IPA dotyczy podwójnej hermeneutyki również w tym sensie, że zajmuje centralną pozycję pomiędzy dwoma wyróżnionymi przez Paula Ricoeura (1970), a przywołanymi przez autorów podręcznika, ujęciami hermeneutyki: opartej na empatii (doświadczenie rekonstruowane jest przy użyciu pojęć, których użyto do jego opisu) i hermeneutyki podejrzeń (wykorzystywane są kategorie pojęciowe, które mają swoje źródło teoretyczne, aby wyjaśnić, zinterpretować fenomen). Rola badacza IPA jest więc dwojaka. Z jednej strony badacz stara się zrozumieć położenie osoby badanej, a z drugiej przygląda się temu pod innym, bardziej krytycznym kątem. Ma to również związek ze zmianą charakteru analiz - od reprezentacji tego, co powiedział respondent do różnych poziomów interpretacji i jest to proces wielokrotnie odnawiany. W tym przypadku prowadzenie analiz nie jest prostym przejściem przez kolejne etapy, ale ciągłym poruszaniem się w obrębie różnych podejść, które mogą odnosić się do „części” albo "całości” analizowanego tekstu (Smith, Flowers, Larkin 2009, s. 28, 36). Słowo „zrozumienie” według autorów najlepiej oddaje dwa aspekty interpretacji w IPA - zrozumienie jako próba wczucia się i wyjaśnienia oraz zrozumienie jako próba nadawania znaczeń. Uznanie tych dwóch aspektów podczas prowadzenia badań może prowadzić do bogatszych analiz i ukazania osoby całościowo - jak piszą autorzy: „bez upiększeń". Co więcej, IPA uznaje wpływ interakcjonizmu symbolicznego, który dotyczy tego, jak znaczenia są konstruowane przez jednostki zarówno w świecie społecznym, jak i osobistym (Smith, Osborn, 2014, 54). 
IPA jest też teoretycznie związana z rozumieniem osoby jako bytu w wymiarze kognitywnym, językowym, afektywnym, fizycznym. Przyjmuje, że występuje związek pomiędzy tym, co człowiek mówi, jego myślami i stanem emocjonalnym. Nie jest to jednak proste połączenie. Ludzie zmagają się z ekspresją tego, co myślą i czują (tutaj może leżeć przyczyna ich niechęci do samoujawniania się), dlatego badacz musi interpretować ich mentalne i emocjonalne stany na podstawie tego, co powiedzieli. IPA skupia się na nadawaniu sensów i znaczeń zarówno przez osobę badaną, jak i badacza, co można opisać jako odczuwanie zrozumienia albo posiadanie porozumienia (ang. having cognition). Autorzy opracowania dotyczącego IPA wskazują na teoretyczny sojusz z psychologią poznawczą co do rozumienia samych procesów poznawczych, ale też na odmienne stanowisko metodologiczne w stosunku do ich badania (Smith, Osborn 2014, s. 54).

Trzecią podstawą teoretyczną jest idiografia, która stoi w opozycji do zasad nomotetycznych. Są one przestrzegane w badaniach, których celem jest ustalenie prawdopodobieństwa, z jakim określone zjawisko może wystąpić, gdy zostaną spełnione pewne warunki (Pietkiewicz, Smith 2012, s. 362). IPA odnosi się natomiast nie do tego, co uniwersalne, ale do tego, co szczególne, i to w dwojaki sposób. Pierwszy charakteryzuje się drobiazgowością prowadzonych analiz. Drugi skupia się na określonym kontekście, branym pod uwagę przy próbie zrozumienia szczególnego doświadczenia, które było udziałem konkretnego człowieka. Dlatego też dobór do próby jest celowy, niewielki i odnosi się do jednostek w określonej sytuacji (Smith, Flowers, Larkin 2009, s. 29-30).

Ten nacisk na szczególność (i koncentrację na rozpoznaniu znaczenia nadanego przez określoną osobę) nie może być ściśle łączony ze skupieniem się na jednostce ze względu na specyficzne fenomenologiczne rozumienie doświadczenia. $Z$ jednej strony jest ono unikalne, usytuowane oraz perspektywiczne - takie rozumienie jest bliskie podejściu idiograficznemu. Z drugiej strony doświadczenie związane jest z byciem w świecie, zanurzeniem się w świat rzeczy i relacji. Nie pasuje tutaj więc typowe rozumienie „osoby”, ponieważ sposób ujawniania się doświadczenia jest rozumiany jako w-relacji-do fenomenu. Nie jest to zatem rzeczywista własność jednostki jako takiej. Jednakże osoba badana może oferować nam swoją osobistą i unikalną perspektywę co do-relacji-do lub zaangażowania w różne fenomeny (Smith, Flowers, Larkin 2009, s. 29). 


\section{Interpretacyjna analiza fenomenologiczna a inne podejścia w badaniach jakościowych}

Wybór podejścia badawczego wiąże się z przyjęciem odmiennego spojrzenia na to, co może stanowić materiał badań, o czym na jego podstawie można wnioskować i co można osiągnąć, analizując zebrane dane. Kluczowe w wyborze podejścia jest więc kryterium epistemologiczne, a właściwie dbałość o to, aby ukryte założenie epistemologiczne w pytaniu badawczym było zgodne $\mathrm{z}$ założeniami sformułowanymi w ramach podejścia badawczego. W ten sposób epistemologia determinuje proces konceptualizacji projektu badań i ma praktyczny wpływ na to, jakie badania realizujemy. Staje się to widoczne krótko po tym, gdy mamy przed sobą zgromadzone dane - istnieje nieskończenie wiele rzeczy, o których możemy wnioskować: proces, znaczenie, intencja itp., dostępne są różne sposoby przyglądania się danym czy wytyczne dotyczące ich kodowania (Smith, Flowers, Larkin 2009, s. 46).

Chociaż badacza IPA interesuje to, w jaki sposób ludzie nadają znaczenia swoim istotnym doświadczeniom życiowym, to kategoria znaczeń, sensów czy doświadczenia nie jest ograniczona tylko do tego podejścia. Istnieje szerokie spektrum możliwości wyboru odpowiedniego podejścia, m.in.: fenomenologia, teoria ugruntowana, analiza dyskursów czy badania biograficzne i narracyjne. W ich obrębie mieszają się różne tradycje, mocniej lub słabiej akcentowane są określone założenia teoretyczne i metodologiczne, ujawniają się wpływy ich twórców czy inspiracja dorobkiem innych badaczy.

Relacja pomiędzy IPA i innymi podejściami w badaniach jakościowych w psychologii uwidacznia się w analizie kluczowych pojęć, takich jak: poznanie, język, kultura, narracja, ucieleśnienie i emocje (Smith, Flowers, Larkin 2009, s. 186). Omówienie różnic i podobieństw w rozumieniu tych kategorii przez przedstawicieli różnych podejść oraz wskazanie praktycznych implikacji, jakie z nich wynikają, przekracza ramy niniejszego artykułu. Pomijając szczegółową charakterystykę każdego podejścia, ukazane zostaną tylko punkty węzłowe łączące IPA z innymi podejściami.

Przedmiotem zainteresowania badaczy IPA jest położenie człowieka jego dylematy i kłopoty lub szerzej - jego radzenie sobie w świecie i ze światem poprzez nadawanie znaczeń swoim doświadczeniom życiowym. Kategoria doświadczenia jest jednak kategorią złożoną i analizowaną od stuleci. Cześć prac fenomenologicznych jest opisem tego, co człowiek spostrzega, czego doświadcza bezpośrednio, ale tym stanom mogą towarzyszyć procesy poznawcze oraz bardziej lub mniej ukierunkowana i uważna refleksja. Smith, Flowers, Larkin (2009, s. 187-190) zauważają, że zachodzi sekwen- 
cyjny proces dochodzenia przez człowieka do refleksji. Według badaczy nie należy ujmować namysłu człowieka tylko na poziomie przedrefleksyjności i refleksyjności. Gdy coś wydarzyło się w naszym życiu, to nie tylko tego doświadczamy bezpośrednio, ale także wspominamy, kojarzymy, wyobrażamy, poddajemy ocenie, próbujemy zrozumieć i wyjaśnić. Część z tych refleksji może być przywołana, ale możliwy jest ponowny namysł nad jej treścią w czasie wywiadu. Innymi słowy, nieświadoma refleksja może za sprawą osoby prowadzącej wywiad stać się ponownie materiałem do świadomej refleksji respondenta i ostatecznie - przedmiotem namysłu samego badacza.

Amadeo Giorgi (2008), podobnie jak twórcy IPA, dokonał operacjonalizacji założeń filozoficznych fenomenologii do praktycznego zastosowania w realizowaniu badań w psychologii. Smith, Flowers i Larkin odwołali się do jego stanowiska, aby wskazać podobieństwa i różnice pomiędzy IPA a fenomenologią. I tak można wskazać, że Giorgi czerpie głównie z myśli Husserla i w swojej metodzie kładzie nacisk na opis, natomiast twórcy IPA nie wybierają jednego stanowiska i określają swoje podejście jako interpretacyjne. To, co różni te dwa podejścia, to także kwestia opracowywania wyników badań i ich prezentacji. Wynika to z faktu, że badacz IPA prowadzi szczegółowe analizy poszczególnych przypadków, natomiast celem analiz fenomenologii według Giorgiego jest ukazanie wspólnotowości doświadczeń, a więc dotarcie do jego istoty. W rezultacie w pierwszym przypadku mamy idiograficzne komentarze interpretacyjne przeplatane $z$ fragmentami wypowiedzi respondentów, a w drugim przypadku - spójny, ejdetyczny obraz fenomenu Smith, Flowers, Larkin 2009, s. 200-201).

Teoria ugruntowana jest często uważana za główną alternatywę dla kogoś, kto rozważa prowadzenie badań przy pomocy IPA. W związku z tym, że teoria ugruntowana ma dłuższą tradycję niż IPA, występuje wiele odmian tego podejścia. IPA i teorię ugruntowaną łączy indukcyjne podejście do danych, ale różni je cel badań, co rzutuje na kwestie metodologiczne. Badacz wykorzystujący teorię ugruntowaną chce wygenerować teorię, która wyłoni się z analizy danych. W związku z tym badania prowadzone są na większej ilościowo, celowo dobranej próbie, aż do jej wysycenia. Natomiast badacz IPA dokonuje szczegółowych i bardziej zniuansowanych analiz doświadczeń życiowych niewielkiej grupy osób, podkreślając podobieństwa i różnice między nimi. Niemniej jednak autorzy podręcznika dopuszczają możliwość prowadzenia analiz i dochodzenia do teorii w sposób, jaki robią to badacze w ramach teorii ugruntowanej (Smith, Flowers, Larkin 2009, s. 201-202).

Występuje więc podobna relacja pomiędzy IPA i fenomenologicznym podejściem Giorgiego w psychologii oraz IPA i teorią ugruntowaną. Jej istota 
polega na różnicy w doborze i liczebności próby, sposobie analiz oraz możliwości uogólniania i prezentacji wniosków (Smith, Flowers, Larkin 2009, s. 202).

Nadawanie znaczeń ma miejsce przy użyciu kilku rodzajów źródeł (narracja, dyskurs, metafora itp.) i w ramach różnych kontekstów (interakcja, taka jak wywiad, otoczenie np. uniwersytet lub szpital). Innymi słowy, kultura jest ramą do nadawania znaczeń. Nadrzędnym celem badań w IPA jest zrozumienie doświadczeń ludzi, ale są one zawsze nieuchronnie uwikłane w język i kulturę. Uznanie kontekstowości, inkulturacji oraz intersubiektywności doświadczeń jest tym, co IPA łączy z interakcjonizmem społecznym oraz psychologią kultury. Po pierwsze, badacz, aby właściwie zrozumieć doświadczenia badanego, musi również posiadać pewien poziom kompetencji kulturowych. Po drugie, interpretacja znaczeń nadawanych przez konkretną osobę musi być dokonywana w określonym kontekście. Cel badań IPA i analizy dyskursów jest jednak odmienny: w pierwszym podejściu badacz zamierza opisać i zinterpretować sensy i znaczenia, w drugim - celem jest dekonstrukcja znaczeń. Przywołana zostaje kategoria dyskursu i dwie odmienne tradycje: dyskurs w kontekście władzy, rozumiany jako część wiedzy, sposób rozumienia, który jest utrzymywany jako konstytutywny (za M. Foucault) albo w wersji etnometodologicznej - dyskurs w kontekście interakcji (za H. Garfinkel i H. Sacks). Można zauważyć pewne wspólne obszary zainteresowań w ramach tych dwóch podejść i IPA, ale istotna różnica, jaka między nimi występuje, dotyczy siły przywiązania do społecznego konstruktywizmu. W IPA uwzględnia się wpływy kultury, ale uznaje się też możliwość przepracowania przez jednostkę tego, co zostało już ukonstytuowane, jej symboliczną i kognitywną aktywność, jako część jej rozwoju. Co więcej, inny jest też przedmiot badań w analizie dyskursów, ponieważ są to dyskursywne reprezentacje, czy to wiedzy, sposobów konstytuowania znaczeń, funkcji interakcji w określonym kontekście itp. Natomiast badacz IPA interesuje się sensami i znaczeniami, które respondenci nadają swoim doświadczeniom (Smith, Flowers, Larkin 2009, s. 191, 195-197).

IPA ma również silne teoretyczne związki z różnymi formami badań narracyjnych. Głównym obszarem zainteresowań badacza IPA jest nadawanie znaczeń a konstruowanie narracji uznano jako jedną z dróg ich nadawania. Badacze analizujący narracje osób badanych mogą koncentrować się na treści tych opowieści i/lub ich strukturze. Interesujące może być również badanie tych struktur, jako społecznie kreowanych konstruktów i poszukiwanie odpowiedzi na pytanie: jakie wzory opowiadania o własnych do- 
świadczeniach ujawniają się w narracjach badanych osób i dlaczego? (Smith, Flowers, Larkin 2009, s. 197)

Konkludując, IPA pozostaje w bliskim związku z innymi podejściami w badaniach jakościowych, ale występujące między nimi różnice uzasadniają wyodrębnienie i dalszy rozwój IPA, jako samodzielnego podejścia badawczego. Mimo że IPA to rama teoretyczna i metodologiczna, którą można wykorzystać do projektowania i realizacji badań, to badaczowi pozostawia się swobodę w doborze metody gromadzenia danych czy ich analizy. Osoba prowadząca badania zobowiązana jest jednak do zachowania spójności w obrębie tego, co ma stanowić materiał badań, o czym na jego podstawie można wnioskować i co można osiągnąć analizując zebrane dane (Smith, Flowers, Larkin 2009, s. 40-41).

Tabela 1. Pytania badawcze w różnych podejściach badawczych

\begin{tabular}{|l|l|l|}
\hline \multicolumn{1}{|c|}{ Pytanie badawcze } & \multicolumn{1}{|c|}{ Kluczowe cechy } & Podejście badawcze \\
\hline $\begin{array}{l}\text { Jakie są główne oparte na } \\
\text { doświadczeniach cechy odczu- } \\
\text { wania złości? }\end{array}$ & $\begin{array}{l}\text { Koncentracja na wspólnej strukturze } \\
\text { złości rozumianej jako doświadczenie }\end{array}$ & Fenomenologia \\
\hline $\begin{array}{l}\text { Jak ludzie, którzy narzekają na } \\
\text { opiekę medyczną, nadają sens } \\
\text { odczuwania złości? }\end{array}$ & $\begin{array}{l}\text { Koncentracja na osobistych znacze- } \\
\text { niach i nadawaniu znaczeń w szcze- } \\
\text { gólnym kontekście, przez ludzi którzy } \\
\text { podzielają konkretne doświadczenia }\end{array}$ & $\begin{array}{l}\text { Interpretacyjna analiza } \\
\text { fenomeno-logiczna }\end{array}$ \\
\hline $\begin{array}{l}\text { Jakiego rodzaju struktur narra- } \\
\text { cyjnych używają ludzie do opisa- } \\
\text { nia wydarzeń, które wzbudzily } \\
\text { w nich złość? }\end{array}$ & $\begin{array}{l}\text { Skupienie się na tym, jak narracja } \\
\text { odnosi się do nadawania znaczeń } \\
\text { (np. przez rodzaj lub strukturę) }\end{array}$ & $\begin{array}{l}\text { Psychologia nar- } \\
\text { racyjna }\end{array}$ \\
\hline $\begin{array}{l}\text { Jakie czynniki wpływają na to, } \\
\text { jak ludzie radzą sobie z odczu- } \\
\text { waniem złości? }\end{array}$ & $\begin{array}{l}\text { Gotowość do opracowania teo- } \\
\text { rii wyjaśniającej (czynniki, wpływy, } \\
\text { oddziaływanie itp.) }\end{array}$ & Teoria ugruntowana \\
\hline $\begin{array}{l}\text { Jak ludzie opowiadają o od- } \\
\text { czuwaniu złości w ich bliskich } \\
\text { relacjach? }\end{array}$ & $\begin{array}{l}\text { Skupienie się na interakcji zamiast } \\
\text { jej treści i ostrożność w wyciąganiu } \\
\text { wniosków o złości jako takiej }\end{array}$ & $\begin{array}{l}\text { Psychologia dyskursy- } \\
\text { wna }\end{array}$ \\
\hline $\begin{array}{l}\text { Jak konstruowana jest złość } \\
\text { w zgłoszeniach dotyczących } \\
\text { incydentów w domach opieki dla } \\
\text { osób starszych? }\end{array}$ & $\begin{array}{l}\text { Gotowość do wykorzystania różnych } \\
\text { źródeł danych, skupienie się na tym, } \\
\text { jak „należy rozumieć” pewne rzeczy } \\
\text { w zależności od konwenansów } \\
\text { danego otoczenia }\end{array}$ & Analiza dyskursu \\
\hline
\end{tabular}

Żródło: Smith, Flowers, Larkin 2009, s. 45 (ttumaczenie własne). 
Smith, Flowers, Larkin opracowali tabelaryczne zestawienie, które ma być wskazówką dla osób, które dokonują wyboru podejścia badawczego. W pierwszej kolumnie umieszczono pytania badawcze dotyczące doświadczania agresji. W odniesieniu do każdego z pytań wskazano, jakie podejście byłoby adekwatne i co wyróżnia każde stanowisko. Nie jest to wyczerpujące zestawienie, a jedynie sugestywna lista głównych podejść badawczych. Jej autorzy dostrzegają również możliwość formułowania pytań, które przecinałyby w poprzek te strategie badawcze (Smith, Flowers, Larkin 2009, s. 43-46).

\section{Uzasadnienie możliwości wykorzystania interpretacyjnej analizy fenomenologicznej w pedagogice/andragogice}

Podstawy badań pedagogicznych wpisują się w złożony charakter pedagogiki jako dyscypliny naukowej, która jest nauką filozoficzno-empiryczno-praktyczną, z całą zawartością poszczególnych określeń i ich tradycją w historii rozwoju metodologii badań naukowych (Nowak 1999, s. 179-180). Ewolucja tożsamości pedagogiki wiąże się ze zmianami, jakie dokonały się w naukach humanistycznych i społecznych w związku z przełomem antypozytywistycznym i budowaniem tożsamości nauk humanistycznych, ale także z przejściem od kultury świata nowoczesnego do kultury świata ponowoczesnego. W efekcie rozwoju tych nauk możemy mówić o istnieniu trzech orientacji metodologicznych, mających odmienny kontekst powstania i odmienne założenia o charakterze filozoficznym. Co za tym idzie, w nauce funkcjonują odmienne preferencje metodologiczne: naturalizm (orientacja pozytywistyczna, uznanie jednego modelu budowania nauki, dominacja empiryzmu), antynaturalizm (związany z humanistycznym rodowodem myślenia pedagogicznego) oraz kulturalizm (uznanie kulturowych i społecznych uwarunkowań formowania się jednostki i grup społecznych; Hejnicka-Bezwińska 2010, s. 58-59; 2015, s. 171). W rozwoju pedagogiki ostatnich dziesięcioleci oprócz reorientacji o charakterze paradygmatycznym ma miejsce także zmiana roli wytwarzających wiedzę o edukacji. Badacz w „płynnej nowoczesności" nie tyle odkrywa i kreuje prawdę opartą na wiedzy pozytywnej, ile rekonstruuje (dekonstruuje) sensy i znaczenia kulturowe, tworzy narracje, uczestniczy w dyskursie $\mathrm{z}$ intencją doskonalenia procesów komunikacyjnych (Hejnicka-Bezwińska 2015, s. 175-176).

Według Stanisława Palki pedagogika w Polsce przez długi czas uprawiana była głównie jako nauka, której metodologiczny wzorzec przyjęty został z nauk przyrodniczych (Ablewicz 1994, s. 5). Dominował w niej ilościowy 
opis rzeczywistości, będący konsekwencją stosowania metod empirycznych. Nie bez wpływu na kształt polskiej pedagogiki była filozofia marksistowska, która preferowała nauki pozytywne wspierające się na "materii”, a nie na "duchu” człowieka (Ablewicz 1994, s. 8). Jednak wiedza wytwarzana przez nauki humanistyczne, do których zaliczana jest pedagogika, musi być tworzona inaczej niż w naukach ścisłych i przyrodniczych - odmienny jest ich przedmiot badań. W naukach humanistycznych mogą być wykorzystywane nie tylko twierdzenia oparte na mierzalnych i obserwowalnych wskaźnikach, ale także twierdzenia oparte na rozumieniu tego, co niepowtarzalne, np. sens, wartości i cel życia ludzkiego, znaczenie indywidualnych doświadczeń ludzkich itp. (Hejnicka-Bezwińska 2010, s. 54). W zależności od celu badań, wytwarzana wiedza informuje nas o jakości danego zjawiska albo przeciętnym, opartym na częstotliwości występowania wskaźników obrazie zjawiska pedagogicznego (Ablewicz 1994, s. 8). Zwolennicy tradycyjnej pedagogiki, broniąc racjonalności instrumentalnej, opowiadają się za redukcją obszaru badań pedagogicznych do tzw. pedagogiki empirycznej. Zwolennicy wyjścia poza dominację jednego paradygmatu opowiadają się za uznaniem wieloparadygmatyczności badań pedagogicznych (Hejnicka-Bezwińska 2010, s. 60). Za przedstawicielkę tego drugiego podejścia można uznać Krystynę Ablewicz. Autorka sprzeciwia się praktykom badawczym, w których analiza duchowości człowieka przeprowadzana jest $\mathrm{z}$ zastosowaniem reguł przyrodoznawstwa, ujęć nomotetycznych i metod statystycznych ${ }^{1}$ (Kubinowski 2010, s. 32). To, co niepowtarzalne, nie może być sprawdzane, czy oceniane według tego, co mierzalne i możliwe do uogólnienia (Ablewicz 1994, s. 7).

Punktem wyjścia powinno być więc zawsze naukowe postawienie problemu, nie metoda. To przedmiot/obiekt ustala metodę, a nie odwrotnie (Danner 1979, s. 14-15, cyt. za: Ablewicz 1994, s. 10). Takie stanowisko dopuszcza stosowanie wielu metod, o ile tylko przyczyniają się one do poznania przedmiotu/obiektu badań, a badacz ma świadomość, czego przy użyciu danej metody zbadać już nie może (Ablewicz 1994, s. 12). Interesujące jest stanowisko Teresy Hejnickiej-Bezwińskiej, która przeciwstawia się tworzeniu odrębnej metodologii badań dla każdej dyscypliny naukowej i formułuje propozycję przesunięcia zainteresowań od tradycyjnie rozumianej metodologii badań pedagogicznych ku problematyce konceptualizacji przedmiotu badań. Rozwiązaniu problemu badawczego ma służyć wspólna naukom hu-

1 Ten problem ma jednak swoją genezę w sporze dotyczącym wzajemnego stosunku nauk przyrodniczych i nauk humanistycznych. Szerzej dotyczy kwestii rozumienia ludzkiego zachowania wraz z jego filozoficznym i historycznym rodowodem (Krasnodębski 1986). 
manistycznym i społecznym skrzynka z narzędziami nazwana metodologią badań naukowych lub metodologią badań społecznych (Hejnicka-Bezwińska 2010, 59-60). Przyjęcie takiego sposobu myślenia uprawomocnia wykorzystywanie różnych podejść badawczych funkcjonujących w obrębie innych nauk humanistycznych i społecznych do realizowania projektów badawczych w pedagogice. Podejście badawcze nie jest ograniczone tylko dla jednej subdyscypliny naukowej. Jedyne ograniczenie wyboru podejścia badawczego wynika z konieczności zachowania spójności z filozoficznymi, teoretycznymi i metodologicznymi założeniami paradygmatu, w ramach którego będzie realizowany projekt. Zdaniem Teda Bentona i Iana Craiba (2003, s. 108) nie ma potrzeby wyboru pomiędzy różnymi koncepcjami w obrębie jednego podejścia, np. interpretacyjnego. $\mathrm{W}$ zamian każdą $\mathrm{z}$ nich można traktować jako właściwą na pewnym poziomie analiz (Ostrouch-Kamińska 2011b, s. 130). Dlatego też interpretacyjna analiza fenomenologiczna może być podejściem wykorzystywanym również w pedagogice pod warunkiem, że postawiony $\mathrm{w}$ badaniach problem będzie korespondował $\mathrm{z}$ wybranym paradygmatem, z którym spójny będzie także wybór podejścia badawczego. W dalszej części artykułu zostaną zaprezentowane przykłady projektów badań pedagogicznych zrealizowanych w ramach perspektywy fenomenologiczno-hermeneutycznej, która stanowi również podstawę interpretacyjnej analizy fenomenologicznej. Odwoływanie się do tych samych założeń filozoficznych wskazywałoby więc na to, że podejście podobne do IPA jest już stosowane w pedagogice humanistycznej.

Chcąc uzasadnić możliwości wykorzystania interpretacyjnej analizy fenomenologicznej w andragogice, konieczne jest przyjęcie kilku założeń. Dotyczą one zmian w obrębie pola badawczego tej dyscypliny oraz towarzyszących im zmian w metodologii badań. Jako punkt odniesienia autorka niniejszego artykułu wybrała analizy Mieczysława Malewskiego, ponieważ zauważa on, że zmiany rzeczywistości społecznej sprawiają, że obowiązujący paradygmat badawczy przestaje „chwytać” kluczowe dla praktyki społecznej problemy. Wspomniany autor sygnalizuje potrzebę wykroczenia poza modernistyczną tradycję oświaty dorosłych i zaakceptowania horyzontu poznawczego, jaki stwarza wizja całościowego uczenia się człowieka, a także wykorzystania podejść rozumiejących do eksploracji procesów uczenia się człowieka dorosłego (Malewski 2010, s. 196, 197).

Kluczowa kwestia dotyczy ewolucji znaczenia terminu „edukacja”, jaka dokonała się na przestrzeni ostatniego półwiecza. W obrębie tego pojęcia sytuowała się niegdyś problematyka samokształcenia, zagadnienia motywacji czy rozwoju zawodowego. Obecnie przedmiotem zainteresowania 
badaczy jest uczenie się biograficzne ludzi dorosłych, rola doświadczenia życiowego w poznawaniu, procesy nabywania i zmiany indywidualnych tożsamości. Uznano, że procesy edukacyjne przebiegają w świecie życia codziennego i konstytuujących je interakcjach społecznych. Najkrócej można powiedzieć, że edukacja dorosłych ewoluuje od „nauczania” poprzez „uczenie się” do „poznawania” (Malewski 2010, s. 19, 58, 74). Przekształcenia w sferze edukacji miały swoje źródła w szerszych zmianach społecznych oraz zmieniających się sposobach postrzegania jednostki i jej związków ze społeczeństwem. Źródłem tych zmian były dwa paradygmatyczne przesunięcia. Po pierwsze, radykalna zmiana nastąpiła po epoce industrialnej, kiedy to dominowała idea strukturalnego determinizmu. Układem odniesienia dla edukacji dorosłych były potrzeby pracy i produkcji oraz role odgrywane w sferze publicznej. W rezultacie odejścia od masowej produkcji standardowych wyrobów oraz rosnącej roli sfery usług zrodziło się zapotrzebowanie na kwalifikację nowego typu i zmiana charakteru edukacji dorosłych. Te przeobrażenia mają daleko idące konsekwencje dla pojmowania indywidualnych tożsamości ludzi i przebiegu ich biografii (Malewski 2010, s. 67-68). Również drugie przejście paradygmatyczne - od nowoczesności do ponowoczesności, pociągnęło za sobą zmianę sposobu widzenia i rozumienia edukacji dorosłych. „Przestaje ona być utożsamiana z instytucjonalną dystrybucją wiedzy i narzucaniem znaczeń. W zamian staje się przestrzenią uczenia się. Towarzyszy temu prawo do podmiotowej interpretacji świata i refleksyjnego bycia w świecie" (Malewski 2010, s. 190). Uwaga badaczy została przeniesiona na osobiste i społeczne rozumienie rzeczywistości przez człowieka, doceniono jego aktywną rolę jako sprawcy i uczestnika procesów społecznych, w tym także procesów uczenia się (Malewski 2010, s. 127). Restrukturyzacji pola badawczego andragogiki towarzyszy również „przesunięcie” metodologiczne, które można zawrzeć w określeniu „od wyjaśniania do rozumienia i interpretacji” (Malewski 2010, s. 137). Przejawem takiego „przesunięcia” może być główna rola badań biograficznych w eksploracji procesów całożyciowego uczenia się dorosłych (Malewski 2010, s. 137).

Za wykorzystaniem IPA w badaniach andragogicznych przemawia nie tylko zmiana stosunku andragogów do kwestii edukacji, ale również dorosłości. Mieczysław Malewski zauważa, że kategoria „dorosłość” nie przyniosła andragogice oczekiwanych rezultatów i proponuje zastąpić ją kategorią "doświadczenia życiowego". Doświadczenie życiowe ludzi ma charakter dialektyczny. „Z jednej strony jest ono uwewnętrznioną kulturą tych światów życia, w których sytuuje się egzystencja i życiowa aktywność ludzi. Z drugiej zakreśla horyzont ich umiejscowienia w kulturze i rozstrzyga o dostępności 
jej symbolicznych zasobów. Tym samym decyduje o możliwości uczenia się i rozwoju na przestrzeni całego życia" (Malewski 2013, s. 37-38). Wykorzystanie kategorii doświadczenia życiowego, uznanie człowieka jako istoty „samointerpretującej się”, ale żyjącej w określonym kontekście społeczno-kulturowym jest więc spójne z podstawami teoretycznymi IPA.

Przyjmując znaczenie edukacji, jako integralnej części aktywności życia człowieka, rodzaj dialektycznej gry między poznaniem, doświadczeniem i działaniem, której celem jest refleksyjna interpretacja składowych świata życia i redefinicja tożsamości podmiotu poznającego (Malewski 2010, s. 58) inspirująca wydaje się mapa autorstwa Duccia Demetria (2006, s. 124-125). Przy jej pomocy można wyznaczyć interesujące andragogów pola badawcze dotyczące doświadczeń życiowych człowieka w szczytowych momentach życia, które generują uczenie się. Takie tematy egzystencjalne występujące w dorosłym życiu jak: miłość, zabawa, praca i śmierć oraz interakcje zachodzące między nimi, a także doświadczenia, które wpisują się w te obszary mogą mieć rzeczywistą lub potencjalną funkcję edukacyjną. Problemy edukacyjne można bowiem dostrzegać niekoniecznie i nie tylko w miejscach oficjalnie związanych z edukacją dorosłych. Rekonstrukcje sensów i znaczeń pozwoliłyby spojrzeć na sposoby ich tworzenia i rozumienia przez ludzi dorosłych w określonej sytuacji życiowej. Możliwe byłoby również umiejscowienie tych analiz w szerszym kontekście rzeczywistości społecznej tworzonej w ramach relacji społecznych, wpływu instytucji, mediów czy w perspektywie globalnej w perspektywie czasów minionych i obecnych, a także wobec istniejących teorii.

\section{Podejście IPA w pedagogice i andragogice - przykłady badań}

Na gruncie polskiej pedagogiki połączenie hermeneutyki, fenomenologii i idiografii w jednym podejściu badawczym nie jest stosowane, niemniej jednak perspektywa fenomenologiczno-hermeneutyczna ma już swoją tradycję w pedagogice. Już na początku lat 90. XX wieku Krystyna Ablewicz zwróciła uwagę na znaczenie, jakie ma hermeneutyczna i fenomenologiczna perspektywa interpretacji rzeczywistości pedagogicznej w konstruowaniu koncepcji pedagogiki, której poznawczą i antropologiczną podstawę stanowi doświadczenie człowieka. Autorka zauważyła wtedy, że mimo dość intensywnego zainteresowania polskich filozofów fenomenologią i hermeneutyką brakuje systematycznego opracowania propagującego możliwość wykorzystania tych podejść w opisie rzeczywistości wychowawczej. Widząc 
potrzebę uzupełnienia tej luki, Ablewicz omówiła podejście hermeneutyczne i fenomenologiczne wraz z opisem aplikowania pewnych założeń do pedagogiki, jako nauki humanistycznej. Pedagogika miała stanowić wyraz filozoficznego "widzenia” człowieka wraz z antropologiczną interpretacją jego doświadczeń. Autorka przyjęła pogląd Ottona F. Bollnowa (cyt. za: Tschamler 1978, s. 148), który ujął pedagogikę jako „hermeneutykę ludzkiej egzystencji”, a więc sztukę rozumienia i objaśniania życia ludzkiego. Skupiając się na pierwotnie danym $\mathrm{w}$ doświadczeniu fenomenie ludzkiej egzystencji poprzez jego opis i ogląd, a następnie jego zrozumienie i interpretacje możliwe jest odsłonięcie prawdy przedmiotu $\mathrm{w}$ charakterystycznym dla niego kontekście (Ablewicz 1994, 8-10, 18, 21-22).

Perspektywa fenomenologiczno-hermeneutyczna jest stale obecna w polskiej pedagogice i andragogice, jej przyjęcie wyznacza kierunek i sposób realizacji badań, jednak w sposób niejednoznaczny. Przyglądając się powstającym publikacjom, okazuje się, że mamy do czynienia z odmiennym rozumieniem fenomenologii, a szczególnie hermeneutyki ${ }^{2}$ oraz uzasadnieniem ich połączenia w jednym podejściu badawczym - co ma swoje konsekwencje w sposobie wykorzystania tego podejścia w praktyce badawczej. Przyjęte rozstrzygnięcia na poziomie założeń ontologicznych i epistemologicznych w różnych projektach badawczych pozostają bardziej lub mniej spójne $\mathrm{z}$ założeniami IPA, to nadal jest to podejście nieznane $\mathrm{w}$ polskiej pedagogice i andragogice. Inaczej sytuacja kształtuje się w krajach z innych obszarów językowych, gdzie coraz częściej pojawiają się deklaracje badaczy nauk o edukacji o wykorzystaniu IPA w swoich badaniach. Te dwa wątki przykłady badań polskich, w których wykorzystano perspektywę fenomenologiczno-hermeneutyczną, oraz przykłady badań zagranicznych, w których zastosowano IPA, zostaną pokrótce omówione.

Najbliższe podejściu IPA wydaje się sposób postępowania badawczego Mirosławy Nowak-Dziemianowicz (2006), która uczyniła przedmiotem swoich badań subiektywne sensy i znaczenia, intencje i interpretacje. Celem badań było przedstawienie i opisanie znaczeń, jakie nadają różnym przejawom swojej codzienności uczestnicy rodzinnego życia (rodzice i dzieci). Autorka odwołuje się do perspektywy fenomenologicznej, która miała dla niej znaczenie inspirujące i jak sama napisała w swojej pracy: „kazała zadać pytania o to, czym jest nadawane przez ludzi ich doświadczeniom zna-

2 Różnice w wykorzystywaniu perspektywy hermeneutycznej wynikają z odmiennego definiowania samej hermeneutyki. Ablewicz (2010, s. 104-106) za Jerzym Stelmachem (1989, s. 4) przywołuje klasyfikację sposobów jej rozumienia. 
czenie, dzięki któremu usensawniają oni swoje działanie. Pozwoliła także zapytać zarówno o granice bezpośredniego wglądu w badaną przeze mnie rzeczywistość, jak i to, czym jest rozumienie siebie, innych ludzi oraz świata, w którym wspólnie żyjemy" (Nowak-Dziemianowicz 2006, s. 58). Natomiast założenia podejścia hermeneutycznego określały kierunek i sposób prowadzonych badań. Autorka przyjęła za Heideggerem (1994), że ludzki byt jest niekończącym się rozumieniem oraz interpretacją, a za Gadamerem, że język określa ludzkie doświadczenie (Gadamer 1993). Osobę oraz jej postępowanie można traktować jako strukturę znaczeniową i tekstową, w związku z czym życie i działanie jednostki można poznawać tak, jak poznaje się „materiały tekstowe". Celem hermeneutyki jest więc zrozumienie, opis i interpretacja doświadczeń człowieka jako tekstu umieszczonego w określonym kontekście społecznym i historycznym. Interpretując tekst będący fragmentem czyjegoś życia, badacz odwołuje się do zawartych w nich sensów i znaczeń, ale spogląda też na nie przez pryzmat własnych przedzałożeń. Nowak-Dziemianowicz przyznaje, że spogląda na sensy i znaczenia respondentów przez pryzmat własnych doświadczeń, co ma pozwolić na zrozumienie tego, co subiektywne, niepowtarzalne i jednostkowe. W ten sposób autorka opowiedziała się za rolą badacza, który dokonuje interpretacji w procesie kolistym, przyjmując, że nie da się zrozumieć bez wcześniejszego rozumienia (Nowak-Dziemianowicz 2006, s. 58-61).

Nowak-Dziemianowicz uzasadnia połączenie tych dwóch podejść w swoich badaniach w sposób następujący: fenomenologia ma służyć dotarciu do znaczeń i sensów badanych fenomenów, a hermeneutyka wyznacza proces interpretacji i rolę badacza (Nowak-Dziemianowicz, 2006, s. 59-61). Takim samym uzasadnieniem posłużyła się Mirosława Nyczaj-Drąg (2011), która przedmiotem opisu, analizy i interpretacji uczyniła „dane narracyjno-biograficzne rodziców klasy średniej, tworzone i przedstawione w kontekście ich doświadczeń biograficznych związanych z edukacją dzieci" (Nyczaj-Drąg 2011, s. 62). Autorka postawiła przed sobą zadanie rekonstrukcji indywidualnych doświadczeń i przeżyć, oczekiwań i planów rodziców związanych z edukacją ich dzieci, odtworzenie i interpretację sensów i znaczeń, jakie rodzice nadają edukacji swoich dzieci.

Zdarza się jednak, że badacz nie deklaruje, jakie jest jego stanowisko, jeśli chodzi o założenia teoretyczne i pisze, że celem jego badań jest odkrycie sensów i znaczeń - jest tak np. w artykule Małgorzaty Malec (2007). Autorka podaje, że „aby zrozumieć badany fragment otaczającego nas świata, by zrozumieć doświadczenia, przeżycia napotykanych w tym świecie ludzi, trzeba dotrzeć do źródeł i umieścić je w strukturach sensów i znaczeń. W po- 
znaniu tych zjawisk, znaczeń, sensów, w »uchwyceniu« ich istoty pomocna jest hermeneutyka i fenomenologia" (Malec 2007, s. 327). Biorąc pod uwagę typologię badań jakościowych w perspektywie fenomenologicznej wyróżnioną przez Clarka Moustakasa (2001, s. 11) ${ }^{3}$ przywołane badania mogłyby zostać przyporządkowane właśnie do hermeneutyki. Perspektywa hermeneutyczno-fenomenologiczna znalazła zastosowanie w psychologii, gdzie uznano, że protokoły opisowe przeżyć domagają się interpretacji analogicznej do interpretacji tekstu, co służyć ma jako pomost do rozumienia sensu zjawiska poddanego badaniu (Moustakas 2001, s. 22).

Zupełnie inne stanowisko $\mathrm{w}$ kwestii rozumienia hermeneutyki przyjęła Joanna Ostrouch-Kamińska (2011a, s. 29, 37), która analizując teoretyczne konteksty fenomenologii rodziny, także odwołuje się do tego podejścia. Autorka powołuje się na Davida M. Kleina i Jamesa M. White’a (1996, s. 108), którzy rozumieją hermeneutykę „nie jako technikę analizy czy określone stanowisko filozoficzne, ale jako metodę rozumienia kontekstualnego oraz sposób, w jaki badacz może, do pewnego stopnia, doświadczać tego, co odczuwa aktor”, co istotnie może zmieniać kierunek i sposób badań. To stanowisko autorka przyjęła również w swoim projekcie badań, który dotyczył rodziny partnerskiej. Jako płaszczyznę interpretacji Ostrouch-Kamińska wykorzystała koncepcję fenomenologii rodziny (opartej na fenomenologii społecznej połączonej z hermeneutyczną interpretacją) oraz założenia konstruktywizmu społecznego. Celem podjętych badań była m.in. próba dokonania pogłębionej analizy codzienności rodzin egalitarnych, sposób jej doświadczania, konstruowania i (re)negocjowania oraz dotarcie do subiektywnych znaczeń, jakie rozmówcy nadają fenomenowi partnerstwa w rodzinie. Przedmiotem badań było doświadczenie, konstruowanie i interpretacje fenomenu partnerstwa między małżonkami/partnerami w rodzinie egalitarnej (Ostrouch-Kamińska 2011b, s. 130-132).

Jak zostało to zauważone, IPA to rama teoretyczna i metodologiczna, którą można wykorzystać do projektowania i realizacji badań. Chociaż badaczowi pozostawia się swobodę w podejmowaniu decyzji o kolejnych krokach postępowania badawczego, to wszystkie rozstrzygnięcia muszą pozostać spójne z założeniami teoretycznymi. Implikowanie IPA do polskiej pedagogiki i andragogiki może być korzystne o tyle, że jest to już podejście w ramach którego połączenie fenomenologii i hermeneutyki jest teoretycznie

3 Moustakas (2001, s. 11) wyróżnił pięć zasadniczych typów badań jakościowych w perspektywie fenomenologicznej: etnografia, teoria badań ugruntowanych, hermeneutyka, fenomenologia empiryczna i heurystyka. 
uzasadnione, opracowane i porządkujące sposób postępowania badawczego. Założenia przyjmowane w projektach badawczych, w których wykorzystuje się IPA nie różnią się od siebie tak, jak założenia w ramach badań, w których przyjmuje się perspektywę fenomenologiczno-hermeneutyczną.

Przykładów badań pedagogicznych, w których wykorzystano podejście IPA jest zdecydowanie mniej niż tych, które dotyczyły psychologii zdrowia. Dokonując przeglądu anglojęzycznych artykułów naukowych w bazie EBSCO na postawie słów kluczy: Interpretative Phenomenological Analysis, pedagogy uzyskujemy 8 wyników, ale już po zmianie hasła pedagogika na edukacja rezultaty wyszukiwania zbliżają się do 500. Spośród wyszczególnionych haseł tezaurusa wybrano te, które wpisują się w pole semantyczne andragogiki4: i uzyskano listę 44 publikacji. Badania, które prowadzono z wykorzystaniem IPA można przyporządkować do następujących grup: 1) doświadczenia „Innych” ze względu na miejsce zamieszkania/pochodzenia np. imigranci, studenci zagraniczni, rdzenni mieszkańcy; 2) doświadczenia „Innych” ze względu na stan zdrowia, możliwości intelektualne, specjalne potrzeby edukacyjne oraz doświadczenia osób bliskich, specjalistów; 3) wykorzystanie środowiska internetowego w edukacji; 4) uczenie się: refleksja w działaniu, doświadczanie, mentoring, praca zespołowa; 5) trajektoria kariery zawodowej, np. radzenie sobie ze zmianą, rozwój zawodowy, profilaktyka wypalenia zawodowego, wybory zawodowe 6) doświadczanie trudności i/lub sposoby radzenia sobie lub udzielania pomocy innym; 7) inne rzadziej występujące: aktywność osób starszych, relacje, adopcja, abstynencja, mniejszości seksualne.

Ze względu na ograniczone ramy niniejszego opracowania nie sposób przybliżyć wszystkich ani nawet części badań przypisanych do wspomnianych grup publikacji. Chcąc zmniejszyć liczbę rezultatów wyszukiwania wyłączono część tekstów, po pierwsze ze względu na tematykę - usunięto te artykuły, które dotyczyły zdrowia (jako bardziej reprezentatywne dla psychologii zdrowia) i po drugie, ze względu na obiekt badań - wyłączono te komunikaty z badań, w których brały udział osoby poniżej 18 roku życia. Dla przykładu zaprezentowano po jednym projekcie badawczym z grup od 1 do $6^{5}$.

4 Uwzględniono następujące hasła: experience, education, experiential learning, students - attitudes, decision making, social support, work, adults, career development, higher education, self-evaluation, career changes, employees - transfer, job involvement, occupational mobility, vocational guidance, work \& family.

5 Prezentując projekt badań, uwzględniono następujące kryteria: przedmiot badań, cel lub pytania badawcze, metody gromadzenia danych, liczebność próby badawczej, wybra- 
Anjam Sultana (2015) przedmiotem swojego zainteresowania uczyniła doświadczenia pięciorga pakistańskich studentów z uniwersytetów West Midlands w Wielkiej Brytanii. Potrzeba przeprowadzenia badań wynikała $\mathrm{z}$ faktu, że pomimo wprowadzanych na uniwersytetach udogodnień, mniejszości etniczne nadal uzyskują niższe osiągnięcia edukacyjne niż ich koledzy. Autorka sformułowała pięć pytań badawczych w kontekście: posiadanych doświadczeń edukacyjnych przed nauką na uniwersytecie i w jej trakcie, dostrzeganych barier i ułatwień w osiągnięciu sukcesu akademickiego, wpływu warunków edukacyjnych na tożsamość, w tym także poczucie bycia studentem uniwersytetu, wpływu tożsamości na zaangażowanie i aspiracje edukacyjne. $Z$ analizy transkrypcji wywiadów wyodrębniono pięć tematów nadrzędnych: tożsamości wielorakie (wieloskładnikowe), tożsamość płciowa, oczekiwania „innych”, szersze wpływy, kontekst uczenia się oraz wysoki status przedmiotów i zawodów. W artykule omówiono tylko pierwszy temat, aby pokazać, jak w złożony i wieloraki sposób instytucje edukacyjne wpływają na doświadczenia pakistańskich studentów.

Doświadczenia opiekunek, które pracują z osobami posiadającymi trudności w uczeniu się w kontekście udziału w kursie oraz własnej praktyki wykorzystywania alternatywnej metody komunikacji z podopiecznymi analizował zespół badaczy z Wielkiej Brytanii (Rayner, Bradley, Johnson, Mrozik, Appiah, Nagra 2016). Projekt dotyczył tego, w jaki sposób najlepiej przygotować osoby udzielające pomocy do wykonywania przez nich pracy, także jeśli chodzi o porozumiewanie się z osobami, które mają poważne i głębokie trudności w uczeniu się. W tym celu trzy osoby wzięły udział w sześciotygodniowym kursie, podczas którego zapewniono respondentom wsparcie, coaching oraz udział w sesjach superwizji. Po pół roku przeprowadzono wywiady z uczestnikami i zapytano ich m.in.: o doświadczane trudności podczas treningu oraz w praktyce zawodowej, ich postawę oraz wpływ na relację z podopiecznymi i innymi pracownikami itp. Badacze podczas analizy wyodrębnili trzy nadrzędne tematy: inwestycja, wyniki, wyzwania. Wyniki badań nie tylko wskazują na pozytywne efekty wykorzystywania alternatywnej metody komunikacji, ale także na zasadność włączania do programu warsztatów sesji coachingowych i superwizyjnych.

Kolejny projekt badawczy zrealizowany przez Sherryn Evans, Tess Knight, Andersa Sønderlunda i Gregory'ego Tooleya (2014) dotyczył doświadczeń moderatorów prowadzących asynchroniczną i synchroniczną

ne wnioski. Jeśli jakiś element został pominięty, to wynikało to z trudności ze znalezieniem lub identyfikacją określonego kryterium w tekście. 
edukację międzybranżową online (ang. interprofessional eduaction - IPE) ${ }^{6}$. Na Wydziale Zdrowia Uniwersytetu Deakin (Australia) przygotowano jeden pełny, dwunastotygodniowy moduł online dla studentów, w którym jednym $z$ elementów była asynchroniczna praca w interdyscyplinarnym zespole wspieranym przez moderatora oraz udział w zebraniach, podczas których analizowano konkretne przypadki pacjentów/klientów. Zadaniem moderatora było kierowanie doświadczeniami uczenia się studentów w tych dwóch aktywnościach. Celem badań było zbadanie doświadczeń moderatów uczestniczących w synchronicznym i asynchronicznym IPE. W wywiadzie telefonicznym wzięło udział 19 moderatorów online. Podczas analizy wyodrębniono dwa nadrzędne tematy: korzyści wynikające z doświadczeń moderowania (dostrzeganie, że studenci się uczą, własny rozwój jako moderatora, elastyczność roli, poczucie bycia wspieranym jako moderator) oraz wyzwania związane z moderowaniem (problemy techniczne, zaangażowanie studentów lub zespołów zarówno w trybie synchronicznym, jak i asynchronicznym), a w ich obrębie wyróżniono jeszcze dodatkowe podtematy. Lepsze zrozumienie tych doświadczeń miało pomóc twórcom programów nauczania kształcić i wspierać moderatorów w wypełnianiu ich roli.

Pam Kennett i Tim Lomas (2015) interesowali się procesem nadawania znaczeń, jako kluczowego fundamentu zaangażowania (także w pracę zawodową) i ogólnego dobrostanu. Autorzy sugerują, że ten proces może zostać ułatwiony poprzez uczestnictwo w relacji mistrz-uczeń. Celem badań było zrozumienie doświadczeń osób, które dobrowolnie pomagały innym jako mentorzy. W badaniu wzięło udział czterech respondentów, którzy posiadali co najmniej dwuletnie doświadczenie i więcej niż jedną okazję udzielenia komuś pomocy. Przed wywiadem uczestnicy zostali poproszeni o przygotowanie przykładów ich mentorskich doświadczeń, aby mogli poddać je refleksji. Wyodrębniono trzy tematy nadrzędne: samoodkrywanie i wzrost, dobre samopoczucie dzięki czynieniu dobra, zarządzenie znaczącym procesem. Bardziej szczegółowe analizy pozwoliły odkryć, że znaczenia rodzą się w ramach silnej kombinacji samodeterminacji (włączając autonomię, powiązanie i kompetencje) i samorefleksji. Co więcej, autorzy zaprezentowali teoretyczny model, który miał odzwierciedlać uzyskane wyniki.

Niamh Murtagh, Paula Lopesa, Evanthię Lyons (2011) zainteresowały doświadczenia osób podejmujących decyzje zawodowe. Badacze zauważyli,

6 W IPE nauka jest interaktywna, polega na aktywnej współpracy, wzajemnym uczeniu się od siebie (nie tylko na zasadzie dzielenia się profesjonalną wiedzą, ale także o pełnionych rolach zawodowych). Stosowane jest przede wszystkim w dziedzinach zdrowia i opieki społecznej. 
że niewiele jest wiadomo na temat innych niż racjonalne aspekty podejmowania decyzji. Postanowiono następujące pytanie badawcze: jak ludzie, którzy dobrowolnie zmienili swoje kariery, doświadczyli podejmowania decyzji. Zmianę kariery zdefiniowano jako transformację, która wymagała dokonania znaczących zmian w rolach, obowiązkach, umiejętnościach i obszarach wiedzy, w której dana osoba miała być ekspertem. Do badań zaproszono osiem kobiet, które w ciągu ostatnich trzech lat zmieniły swoje kariery. Przeprowadzono z każdą osobą dwa oddzielne wywiady - pierwszy dotyczył uczuć i doświadczeń związanych z podjęciem decyzji o zmianie, a drugi z nową posadą. Podczas analiz wyodrębniono dwa tematy nadrzędne, które dotyczyły ogólnie procesu podejmowania decyzji o zmianie pracy: działanie bezplanowe i pozytywne emocje oraz konstruowanie decyzji. Autorzy zaproponowali ramę teoretyczną podejmowania decyzji, w której wyróżniono trzy elementy: akcja, afekt, poznanie, wskazując w ten sposób na istotną rolę emocji oraz znaczenia procesów samoregulacji.

Z kolei Andrew Denovan i Ann Macaskill (2013) zauważyli, że brakuje opracowań dotyczących tego, jakie są doświadczenia osób rozpoczynających naukę w szkole wyższej w kontekście radzenia sobie ze stresem w sytuacji przystosowania się do nowej sytuacji. Z dziesięcioma studentami pierwszego roku zostały przeprowadzone wywiady, z czego siedem osób mieszkało z dala od domu, a pięciu respondentów pracowało jakiś czas. Badacze wyodrębnili pięć głównych tematów, które ujawniły się w czasie analizy: wszystkie zmiany, oczekiwania względem uczelni, studiowanie, sieci wsparcia, trudności. Studenci wykorzystali szereg strategii radzenia sobie ze stresem - te związane z pozytywnymi psychicznymi zasobami okazały się pomocne w regulacji i procesie przystosowania w nowych warunkach.

\section{Krytyczna ocena IPA - ograniczenia i możliwości stosowania podejścia}

Krytycznej oceny IPA można dokonać w kontekście trzech aspektów: po pierwsze, przyglądając się dyskusji prowadzonej na łamach czasopism naukowych na temat IPA, po drugie, wykorzystując doniesienia innych badaczy o ewentualnych trudnościach metodologicznych lub oceniając jakość dotychczasowych publikacji, w których prezentowano wyniki badań uzyskane przy zastosowaniu tego podejścia, po trzecie, zastanawiając się nad ograniczeniami i możliwościami zastosowania IPA w polskiej pedagogice/andragogice. 
Interesującą dyskusję prowadzili ze sobą: Jonathan Smith - uznawany za twórcę IPA, oraz Amedeo Giorgi - twórca opisowej metody fenomenologicznej w psychologii. Giorgi (2011, s. 215; 2010, s. 4) w swojej krytyce IPA stwierdził, że „IPA ma niewiele wspólnego z dwudziestowieczną filozofią fenomenologiczną i jej metodologiczne procedury nie spełniają kryterium naukowości”. Jeśli chodzi o pierwszą część tej krytycznej oceny, to zdecydowana większość sformułowanych zarzutów dotyczy tego, w jaki sposób wykorzystano i połączono różne założenia fenomenologiczne i/lub hermeneutyczne. Według ich autora przywołane tezy są potraktowane powierzchownie i ogólnikowo, a eklektyczność metody nie jest jej zaletą, ale wadą, bo w jej obrębie skumulowano sprzeczne ze sobą rozumienia kluczowych pojęć. Pojawia się nawet stwierdzenie, że twórcy IPA najpierw opracowali metodę, a następnie szukali punktów podparcia w tradycji filozoficznej ${ }^{7}$. Giorgi (2011, s. 198) formułuje swoje wątpliwości co do trzech aspektów: (1) zamieszanie w użyciu terminu „wzięcia w nawias”, (2) utożsamiania postawy fenomenologicznej z aktem refleksji, (3) niewspominanie o fenomenologicznej redukcji, która jest kluczowa w psychologii fenomenologicznej.

Drugi zarzut dotyczy kryterium naukowości: kwestii tego, czy IPA traktować jako pewien schemat badawczy bądź procedurę, której którego badacz powinien się trzymać, czy jest to pewna propozycja, zwłaszcza że pozostawia się badaczowi swobodę. W kontekście tej elastyczności postępowania badawczego Giorgi stawia kolejne pytania, ponieważ zauważa, że wiele pisze się o tym, co jest istotą metody, do czego należy dążyć, co można zrobić, a niewiele poświęca się miejsca na wyjaśnienie, „jak” określona idea się przejawia, w jaki sposób wykorzystać tę elastyczność, jak osiągnąć określone nastawienie fenomenologiczne itp. Autor zastanawia się również nad możliwością powtórzenia i sprawdzenia badań, kwestią subiektywności wyników. Tutaj warto przywołać stanowisko Smitha, który jako kryteria oceny ważności i trafności badań jakościowych przyjął propozycję Lucy Yardley (2000), która wyróżniła: wrażliwość na kontekst, zaangażowanie i dokładność/rygor, transparentność i spójność oraz wpływ i ważność. Według Smitha (2010, s. 188) trudno jest mówić o powtarzalności badań jakościowych, ponieważ nawet wtedy, gdy wywiady będą przeprowadzane przez dwie, równie kompetentne osoby, korzystające $z$ tego samego planu rozmowy, to efekt ich prac będzie się różnił. Możliwa i pożądana jest natomiast ocena ich trafności np. przez promotora/opiekuna naukowego i/lub audytora oraz

7 „Rather, they seemed to have first formulated a method and then searched for links to philosophical traditions". 
czytelnika. Monitorowany może być proces gromadzenia danych (sprawdzenia dyspozycji do wywiadu, przygotowanych transkrypcji), proces analityczny (tworzenie notatek, kodów, tematów) i etap sporządzenia raportu z badań, w którym opisane zostaną kolejne kroki postępowania badawczego wraz z częścią analityczną - spójną, ciągłą i dobrze udokumentowaną (2011, s. 180-184).

Jak pokazują badana Smitha (2011), nie wszystkie komunikaty z badań spełniają wskazane powyżej kryteria. Autor opracował zbiór wskaźników, na podstawie których ocenił jakość 293 artykułów z zakresu psychologii zdrowia. Około 27\% tekstów zostało uznanych za „dobre”, kolejne 55\% publikacji było do zaakceptowania, a pozostałych $18 \%$ nie można było ocenić pozytywnie. Te ostatnie najczęściej nie były zgodne z teoretycznymi zasadami IPA, były niedostatecznie przejrzyste dla czytelnika, aby mógł zrozumieć, co zostało zrobione, były także niedostatecznie interesujące i słabo udokumentowane. W przeważającej mierze to ostatnie kryterium decydowało o niskiej ocenie artykułu. Zbyt duża liczba opisowych tematów, niewystarczająca liczba dołączonych fragmentów wypowiedzi respondentów, brak interpretacji przywoływanych cytatów, brak określenia częstotliwości występowania tematów i wyjaśnienia, czym zdeterminowana jest ich powszechność, zbyt proste analizy bez ich zniuansowania to główne zarzuty skierowane do autorów ocenianych publikacji (Smith 2011, s. 17; 24-25). To także najczęściej popełniane błędy przez studentów, a także osoby, które dopiero uczą się warsztatu badacza IPA. Najczęściej są one efektem realizacji projektu badań, który powstał na podstawie błędnie przyjętych założeń dotyczących stosowanego podejścia. Według Kate Hefferon i Eleny Gil-Rodriguez (2011) źródłem tych problemów jest powód, dla którego studenci wybierają IPA do realizacji własnych badań. Ich zdaniem IPA to prosta wersja tematycznych analiz z niewielkim naciskiem na interpretacje, dlatego może być uważana za niesprawiające trudności podejście badawcze. W konsekwencji studenci wybierają najpierw metodologię, a dopiero później zastanawiają się nad sformułowaniem celu i pytań badawczych, które powinny być wygenerowane, jako skutek zauważenia potrzeby przeprowadzenia określonych badań. Co więcej, odczuwają oni naciski, aby włączyć do badań zbyt wielu uczestników czy nawet zorganizować grupę kontrolną. Wiąże się to z preferowaniem przez opiekunów naukowych badań ilościowych i potrzebą zobiektywizowania wyników badań. Przyjęcie takiego rozwiązania jest sprzeczne z przywiązaniem IPA do idiografii, a w konsekwencji powoduje, że analizy pojedynczych przypadków nie mogą być wystarczająco szczegółowe, głębokie, zniuansowane i kontekstualne. Nie sposób też dokonać satysfakcjonują- 
cego porównania podobieństw i różnić między respondentami czy grupami i przy tym odpowiednio to udokumentować fragmentami wypowiedzi. Co ważne, badacze IPA nie dążą do uogólniania wyników badań, a raczej do teoretycznej przekładalności, czyli do tego, aby czytelnik mógł ocenić rezultaty $\mathrm{w}$ relacji do istniejącej profesjonalnej i empirycznej wiedzy. Hefferon i Gil-Rodriguez (2011, s. 758), opierają się na własnych doświadczeniach w nauczaniu, ale także prowadzeniu badań $\mathrm{z}$ wykorzystaniem IPA, sugerują przestrzeganie zasady „mniej znaczy więcej”: mniej osób badanych, mniej pytań w planie wywiadu, mniej nadrzędnych i podrzędnych tematów analiz. Ich zdaniem lepiej przeprowadzić szczegółowe analizy kilku przypadków niż ryzykować, że nadmiar zgromadzonego materiału będzie rzutował na jakość efektów naszej pracy.

Ostatni aspekt, w jakim można krytycznie ocenić IPA to możliwości i ograniczenia co do możliwościami zastosowania IPA w polskiej pedagogice/andragogice. Jak zostało to wcześniej omówione, IPA ma silne teoretyczne związki z różnymi formami badań narracyjnych, które przeżywają dziś swoiste odrodzenie, zwłaszcza w andragogice europejskiej (A. Jurgiel, 2011, s. 94). M. Malewski (2010, s. 137-138) jednak krytycznie ocenia stosowane praktyki badawcze i uważa, że prowadzone badania bywają przykładem uprawiania nauki pozytywistycznej z zastosowaniem postpozytywistycznej metodologii. Autor wymienia cztery typy błędów: 1) postawę naiwnego psychologizmu, 2) nacisk kładziony na faktualność biografii, 3) statyczność perspektywy poznawczej oraz 4) ateoretyczność badań". Alicja Jurgiel również zauważa, że stosowane praktyki badawcze w ramach badań narracyjnych w niewielkim stopniu świadczą o zaawansowanej wiedzy dotyczącej epistemologii i wysokiej świadomości metodologicznej badacza. Zidentyfikowane praktyki badawcze autorka nazywa: wiernością procedurze, wyczarowaniem wyników badań, szukaniem ilustracji w postaci fragmentu narracji do tezy wytwarzanej w trakcie analizy danych czy traktowaniem badań biograficznych jako dyskursywnych (A. Jurgiel, 2011, 93-94, 96).

Należy zauważyć, że włączenie nowego podejścia, jakim jest interpretacyjna analiza fenomenologiczna, do „skrzynki z narzędziami”, z której skorzystają pedagodzy i andragodzy, nie wyeliminuje popełnianych przez badaczy "grzechów" w prowadzeniu badań. Chociaż IPA stanowi ramę metodologiczną, która określa teoretyczne i praktyczne wskazówki dotyczące konstruowania projektu badawczego, to jego faktyczna realizacja zależy od badacza - począwszy od postawienia problemu badawczego korespondującego $\mathrm{z}$ wybranym paradygmatem, z którym spójny będzie także wybór podejścia badawczego, a skończywszy na gromadzeniu i analizie danych. Jeśli 
jednak przyjmiemy założenia IPA, to zarzuty sformułowane przez Malewskiego i Jurgiel dotyczące stosowanych praktyk badawczych nie powinny mieć zastosowania do projektów realizowanych przy pomocy tego podejścia. Po pierwsze, badacz IPA wychodzi poza przedstawianie faktów z życia osób badanych i dokonuje hermeneutycznej interpretacji tego, o czym powiedzieli badani. Po drugie, prowadzone analizy zmierzają w stronę ujawniania mechanizmów wytwarzania narracji przy uwzględnieniu kontekstu życia jednostki, ale też szerszych procesów społeczno-kulturowych oraz istniejących teorii. Po trzecie, z jednej strony badacza obowiązują hermeneutyczne procedury analizy treści, ale $\mathrm{z}$ drugiej pozostawia mu się swobodę w dochodzeniu do rezultatów badań - o ile zachowana zostanie spójność epistemologiczna.

W związku z tym, że brakuje doniesień z badań przeprowadzonych przy pomocy IPA przez polskich pedagogów i andragogów, trudno jest faktycznie wskazać na inne, specyficzne ograniczenia czy możliwości, które mogą wystąpić tylko w zakresie pedagogiki i andragogiki, a które nie zostały wspomniane w dwóch pierwszych aspektach, tj. w kontekście dyskusji o teoretycznych założeniach podejścia i jego praktycznym zastosowaniu, także przyglądając się publikowanym komunikatom z badań i trudnościom, jakie doświadczają osoby, które dopiero uczą się stosowania IPA

\section{Bibliografia}

Ablewicz K. (1994), Hermeneutyczno-fenomenologiczna perspektywa badań w pedagogice, Zakład Poligraficzny UJ, Kraków.

Ablewicz K. (2010), Hermeneutyka i fenomenologia a pedagogika, [w:] S. Palka (red.), Podstawy metodologii badań w pedagogice, Gdańskie Wydawnictwo Psychologiczne, Gdańsk.

Benton T., Craib I. (2003), Filozofia nauk społecznych. Od pozytywizmu do postmodernizmu, Wydawnictwo Dolnośląskiej Szkoły Wyższej Edukacji TWP, Wrocław.

Danner H. (1979), Methoden geiteswissenschaftlicher Pädagogik. Einführung in Hermeneutik, Phänomenologie und Dialektik. München/Basel.

Demetrio D. (2006), Edukacja dorosłych, [w:] B. Śliwerski (red.), Pedagogika, t. 3: Subdyscypliny wiedzy pedagogicznej, Gdańskie Wydawnictwo Psychologiczne, Gdańsk.

Denovan A., Macaskill A. (2013), An interpretative phenomenological analysis of stress and coping in first year undergraduates, „British Educational Research Journal" 39(6). 
Evans H., Knight T., Sønderlund A., Tooley G. (2014), Facilitators' experience of delivering

asynchronous and synchronous online interprofessional education, „Medical Teacher”, 36(12).

Gadamer H. (1993), Prawda i metoda, Inter-esse, Kraków.

Giorgi A. (2011), IPA and Science: A Response to Jonathan Smith, „Journal of Phenomenological Psychology" 42.

Hefferon K., Gil-Rodriguez E. (2011), Interpretative phenomenological analysis, „The Psychologist", 24(10).

Heidegger M. (1994), Bycie i czas, przekł. B. Baran, Wydawnictwo Naukowe PWN, Warszawa.

Hejnicka-Bezwińska T. (2010), Badania nad edukacja w perspektywie poznawczej współczesnych nauk społecznych i humanistycznych, [w:] S. Palka (red.), Podstawy metodologii badań w pedagogice, Gdańskie Wydawnictwo Psychologiczne, Gdańsk.

Hejnicka-Bezwińska T. (2015), Pedagogika. Podręcznik dla pierwszego stopnia ksztatcenia na poziomie wyższym, Difin, Warszawa.

Jurgiel A. (2011), Praktyki badawcze obecne w badaniach biograficznych nad procesami społeczno-kulturowego uczenia się dorostych. Ujęcie krytyczne, „Edukacja Dorosłych", 2.

Kennett P., Lomas T. (2015), Making meaning through mentoring: Mentors finding fulfilment at work through self-determination and self-reflection, „International Journal of Evidence Based Coaching \& Mentoring", 13(2).

Klein D. M., White J. M. (1996), Family Theories. An Introduction, Thousand Oaks, Sage Publications, London, New Delhi.

Kubinowski D. (2010), Przyrodnicze i humanistyczne podstawy badań pedagogicznych, [w:] S. Palka (red.), Podstawy metodologii badań w pedagogice, Gdańskie Wydawnictwo Psychologiczne, Gdańsk.

Malec M. (2007), Spotkanie własnej inności. Doświadczenie niepełnosprawności w narracjach, [w:] E. Kurantowicz, M. Nowak-Dziemianowicz (red.), Narracja, krytyka, zmiana. Praktyki badawcze we współczesnej pedagogice, Wydawnictwo Naukowe Dolnośląskiej Szkoły Wyższej Edukacji TWP, Wrocław.

Malewski M. (2010), Od nauczania do uczenia się. O paradygmatycznej zmianie w andragogice, Wydawnictwo Naukowe Dolnośląskiej Szkoły Wyższej, Wrocław.

Malewski M. (2013), „Dorosłość” - kłopotliwa kategoria andragogiki, „Teraźniejszość - człowiek - edukacja", (63)3.

Moustakas C. (2001), Fenomenologiczne metody badań, przekł. i red. S. Zabielski, Trans Humana Wydawnictwo Uniwersyteckie, Białystok.

Murtagh N., Lopes P., Lyons E. (2011), Decision Making in Voluntary Career Change: An Other-Than-Rational Perspective, „Career Development Quarterly”, 59(3).

Nowak M. (1999), Podstawy pedagogiki otwartej, RW KUL, Lublin. 
Nowak-Dziemianowicz M. (2006), Doświadczenia rodzinne w narracjach. Interpretacje sensów i znaczeń, Wydawnictwo Naukowe Dolnośląskiej Szkoły Wyższej Edukacji TWP, Wrocław.

Nyczaj-Drąg M. (2011), Rodzice z klasy średniej wobec edukacji dziecka - koncepcja badań własnych, [w:] A. Gajdzica, A. Minczanowska, M. Stokłosa (red.), Orientacje jakościowe w badaniach pedagogicznych, Oficyna Wydawnicza „Impuls”, Cieszyn-Kraków.

Ostrouch-Kamińska J. (2011a), Teoretyczne konteksty fenomenologii rodziny, [w:] A. Gajdzica, A. Minczanowska, M. Stokłosa (red.), Orientacje jakościowe w badaniach pedagogicznych, Oficyna Wydawnicza „Impuls”, Cieszyn-Kraków.

Ostrouch-Kamińska J. (2011b), Rodzina partnerska jako relacja wspótzależnych podmiotów. Studium socjopedagogiczne narracji rodziców przeciążonych rolami, Oficyna Wydawnicza „Impuls”, Kraków.

Pańczak A, Pietkiewicz I. (2015), Aktywność zawodowa w procesie zdrowienia-interpretacyjna analiza fenomenologiczna doświadczeń pacjentów ze spektrum schizofrenii, „Psychiatria Polska”, 6.

Pietkiewicz I. (2015) Reaching a decision to change vocation: a qualitative study of former priests' experiences, „International Journal for Educational and Vocational Guidance", 10.

Pietkiewicz I., Smith J. A. (2012), Praktyczny przewodnik interpretacyjnej analizy fenomenologicznej $w$ badaniach jakościowych $w$ psychologii, „Czasopismo Psychologiczne", 18(2), s. 361-369.

Rayner K., Bradley S., Johnson G., Mrozik J. H., Appiah A., Nagra M. K. (2016), Teaching intensive interaction to paid carers: using the "communities of practice" model to inform training, „British Journal of Learning Disabilities”, 44(1).

Ricoeur P. (1970), Freud and Philosophy: An Essay on Interpretation, Yale University Press, New Haven.

Smith J. A. (1996), Beyond the divide between cognition and discourse: Using interpretative phenomenological analysis in health psychology, „Psychology \& Health”, 11.

Smith J. A. (2010), Interpretative Phenomenological Analysis. A Reply to Amedeo Giorgi, „Existential Analysis”, 21.

Smith J. A., Flowers P., Larkin M. (2009), Interpretative Phenomenological Analysis. Theory, Method and Research, Sage, Los Angeles [etc.].

Smith J. A., Osborn M. (2014), Qualitative Psychology. A practical guide to research methods, Sage, Los Angeles [etc.].

Stelmach J. (1989), Co to jest hermeneutyka, Zakład Naukowy im. Ossolińskich, Wrocław-Warszawa-Gdańsk-Łódź.

Sultana A. (2015), "I don't see how that makes me a gori (White girl)”: The multiple and problematic identities of academically successful Pakistani students, „Educational \& Child Psychology", 32(2).

Tschamler H. (1978), Wissenschaftstheorie. Eine Einführung für Pädagogen, Bad Heilbrunn. 